\title{
Not Known if IDH Family Mutation Analysis Was Performed
}

National Cancer Institute

\section{Source}

National Cancer Institute. Not Known if IDH Family Mutation Analysis Was Performed. NCI Thesaurus. Code C160455.

An indication that it is not known whether IDH family mutation analysis was performed during the study. 